\title{
DESTINATION SATISFACTION AND REVISIT INTENTION OF TOURISTS: DOES THE QUALITY OF AIRPORT SERVICES MATTER?
}

\author{
Boopen Seetanah \\ Viraiyen Teeroovengadum \\ Robin S Nunkoo \\ University of Mauritius
}

\begin{abstract}
This study focuses on the link between tourists' satisfaction with the quality of airport services at a destination and their intention to revisit. The influence of tourists' overall satisfaction with a destination on their behavioral intentions has been well established both at theoretical and empirical levels; however, the particular role of satisfaction with airport services has been so far largely neglected. Researchers have recognized the vital importance of tourists' experience with airport services because of the fact that the airport is the first and last encounter that they experience when visiting a country. As such, the focus of the present study pertains to evaluating the satisfaction level of tourists visiting Mauritius and examining its resulting effect on their behavioral intentions. The study uses the survey methodology for data collection and involved the distribution of self-administered questionnaires to a sample of 1,721 tourists at the SSR airport in Mauritius. Exploratory factor analysis is used to extract meaningful dimensions of airport services and a multinomial probit analysis is conducted to test for the impact of satisfaction with airport services on revisit intention while taking into account other control variables. Interestingly, airport services are seen to significantly influence the probability of repeat tourism.
\end{abstract}

KEYWORDS: airport services; quality; destination satisfaction; loyalty; revisit; tourism

The importance of repeat tourism for the sustainability of the tourism sector has been well established by past research (J. S. Chen \& Gursoy, 2001; Hung, Lee, \& Huang, 2016; Kozak, 2001; Quintal \& Polczynski, 2010; Stylos, Bellou, Andronikidis, \& Vassiliadis, 2017). In the long term, repeat tourism has been shown to be less costly than reliance on first-time visitors and thus the sustained growth of a destination's tourism sector relies greatly on tourists who repeat their visits (Um, Chon, \& Ro, 2006). Given the importance of repeat tourism, much effort has been made by past studies to understand the antecedents of 
tourists' revisit intention and in line with findings from consumer behavior research, it has been found that satisfaction with the destination is a major determinant. Zhang, $\mathrm{Wu}$, and Buhalis (2017) highlighted the importance of tourists' experience in determining their revisit intention. Similarly, many past empirical studies have demonstrated that tourists' experiences and their satisfaction with a destination are major determinants of their intention to revisit the destination (Choo \& Petrick, 2014; Petrick, Morais, \& Norman, 2001; Ranjbarian \& Pool, 2015; Um et al., 2006).

Despite the progress made in the understanding of satisfaction with various components of a destination and its impact on tourists' intention to revisit, there is still a need for a better comprehension of the attributes of a destination that determine destination satisfaction. Although the importance of transportation services to tourism development in general has been well established (Khadaroo $\&$ Seetanah, 2007), the review of the extant literature showed little focus on the role played by satisfaction of tourists with the quality of airport services. Importantly, Seyanont (2011) observed that "airport infrastructure is the first and last point of tourists' contact in their holiday destination," whereas Chao, Lin, and Chen (2013) further argued that "international travellers' impressions of a particular country are frequently affected by their first and last encounters at the gateway airport." We, therefore, argue that at a destination level the satisfaction of tourists with airport services has a major role to play. Although there have been research done on the assessment of the quality and satisfaction of tourists with airport services (Bezerra \& Gomes, 2015; Fodness \& Murray, 2007; Lubbe, Douglas, \& Zambellis, 2011; Martín-Cejas, 2006; Tsai, Hsu, \& Chou, 2011; Yeh $\&$ Kuo, 2003), these have not investigated its impact on revisit intention. This study, therefore, aims to bridge this gap in the literature by investigating into the contribution of tourists' satisfaction with airport services to their intention to revisit a destination.

As such, given the above, the aim of the present study is twofold: first, to identify the main dimensions of airport services contributing to tourists' satisfaction and second, to assess the impact of the dimensions uncovered on repeat tourism using a multinomial probit model while taking into account tourists' satisfaction with other components of the destination such as satisfaction with accommodation services, attractions, and cost of living.

\section{CONCEPTUAL FRAMEWORK AND HYPOTHESES}

The relationship between satisfaction and customers' behavioral intentions in the services sector has been extensively researched during the past decades. Fornell (1992) suggested that the more customers were satisfied with services they received the greater would be their intention to engage in favorable behaviors with respect to their service provider and the less would be their intention to switch to alternative service providers. Subsequently, numerous empirical studies in the generic services literature have argued for a positive association 
between customer satisfaction and favorable behavioral intentions (Brady \& Cronin, 2001; Cronin, Brady, \& Hult, 2000; Ladhari, 2009; Zeithaml, Berry, \& Parasuraman, 1996).

In the tourism context, recognizing the importance of satisfaction in predicting tourists' behavioral intentions, various studies have sought to investigate into the relationship between these two variables at destination level. The link between tourists' level of satisfaction with a destination and their intention to revisit the destination is grounded in the theory of destination choice set (Crompton, 1992). According to the latter tourists select destinations with attributes that they believe will best satisfy their needs. As argued by Stylos et al. (2017) tourists' intention to return to a destination is also determined by the extent to which they perceive that the attributes of a destination shall meet their needs.

A stream of research has established that the more tourists' express their satisfaction with a destination the more likely they are to revisit the destination (Assaker, Vinzi, \& O'Connor, 2011; C.-F. Chen \& Chen, 2010; C.-F. Chen \& Tsai, 2007; Chi \& Qu, 2008; Del Bosque \& Martín, 2008; Hutchinson, Lai, \& Wang, 2009; Lee, Lee, \& Lee, 2005; Loi, So, Lo, \& Fong, 2017; Petrick et al., 2001; Ranjbarian \& Pool, 2015; Um et al., 2006; Zhang et al., 2017). Tourists' revisit intention which refers to their perceived likelihood of coming back to the same destination is a specific element of favorable postconsumption behavior and is key component of tourism loyalty (Cole \& Scott, 2004; Loi et al., 2017). On the other hand, destination satisfaction has been specifically defined as "the aggregate feelings that one derives as a result of visiting a tourist attraction" (Cole \& Scott, 2004, p. 81).

While the positive impact of destination satisfaction on tourists' intentions to revisit a destination appears to be undeniable, destination experience has been found to be complex and comprising various components (Pizam \& Milman, 1993). When using a factor-specific approach to measuring satisfaction and viewed as a multidimensional construct (Sureshchandar, Rajendran, \& Anantharaman, 2002), it becomes important to understand which dimension of destination satisfaction contributes more to fostering favorable behaviors. Past studies have focused on different destination satisfaction components such as shuttle services (Loi et al., 2017), perceived attractiveness (Um et al., 2006), perceived justice (Kim et al., 2017), perceived risk (J. V. Chen, Htaik, Hiele, \& Chen, 2017), memorable experiences (Zhang et al., 2017), and public transport (Thompson \& Schofield, 2007). Of particular interest to the present study are those studies which focused on satisfaction with transportation services available at a destination. The results have been inconclusive. While Danaher and Arweiler (1996) found that transportation services had no direct effect on tourists' revisit intention, Thompson and Schofield (2007) and Zhang et al. (2017) both concluded that transport-related services were important determinants of both satisfaction and revisit intention.

The quality of airport services has been identified as an essential element of destination satisfaction and accordingly the evaluation of tourists' satisfaction 
Figure 1

Conceptual Framework

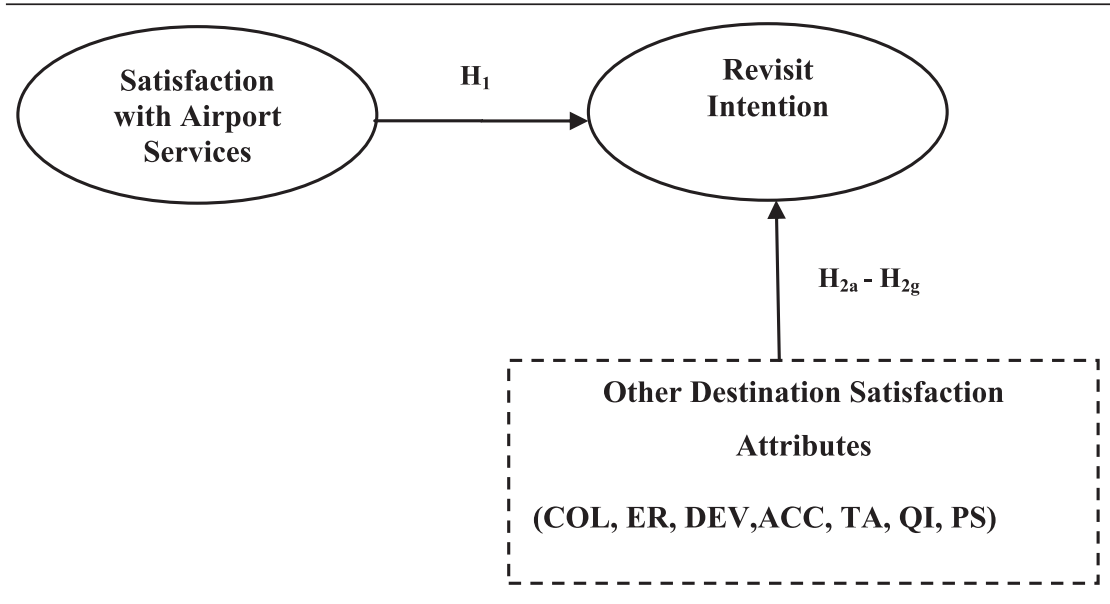

Note: $\mathrm{ACC}=$ satisfaction with hotel/accommodation quality; $\mathrm{COL}=$ satisfaction with cost of living (COL); DEV = satisfaction with development level; TA = satisfaction with quality of tourism attractions; PS = satisfaction with political stability; QI = satisfaction with quality of information; $E R=$ satisfaction with exchange rate.

with airport services has been given due consideration by past research (Bezerra \& Gomes, 2015; Fodness \& Murray, 2007; Lubbe et al., 2011; Martín-Cejas, 2006; Tsai et al., 2011; Yeh \& Kuo, 2003). As noted by Martín-Cejas (2006), tourism service quality begins at the airport. It follows that as a major determinant of overall destination satisfaction, the satisfaction of tourists with airport services is bound to influence their revisit intention. The following hypothesis is therefore proposed:

Hypothesis 1: Satisfaction of tourists with airport services has a direct positive effect on their revisit intention.

While the focus on the present study is to test the above hypothesis, it is important to test it in light of other important predictors of tourists' revisit intention. Based on the extant literature in the tourism literature, a set of other destination satisfaction attributes are identified and can be considered as control variables (Figure 1). The destination satisfaction attributes are satisfaction with hotel/accommodation quality (ACC), satisfaction with cost of living (COL), satisfaction with development level (DEV), satisfaction with attractions quality (TA), satisfaction with political stability (PS), satisfaction with quality of information (QI), and satisfaction with exchange rate (ER).

Satisfaction of tourists with cost of living has been found to be an important attribute of destination satisfaction and a determinant of revisit intention. Some 
studies consider overall satisfaction with price as a component of destination satisfaction and provide empirical evidence with regard to its importance in shaping tourists' overall satisfaction with a destination (N. Chen \& Funk, 2010; Hui, Wan, \& Ho, 2007; Hutchinson et al., 2009; Ranjbarian \& Pool, 2015). Consequently, the following hypotheses are proposed:

Hypothesis 2a: Satisfaction of tourists with the destination's cost of living has a direct positive effect on their revisit intention.

Hypothesis 2b: Satisfaction of tourists with the destination's exchange rate has a direct positive effect on their revisit intention.

The overall quality of a destination's infrastructure has also been identified as a major predictor of tourists' loyalty level. N. Chen and Funk (2010) and Hui et al. (2007) found elements of destination infrastructure such as transportation facilities and shopping malls to be important components of destination satisfaction and significant determinants of tourists' revisit intention. In the same vein, Loi et al. (2017) found that the infrastructure quality of a destination is a good predictor of tourists' revisit intention. We therefore propose the following hypothesis:

Hypothesis 2c: Satisfaction of tourists with the destination's development state (infrastructure quality) has a direct positive effect on their revisit intention.

Satisfaction of tourists with accommodation services has been identified as another important contributor of tourists' overall destination satisfaction and as a predictor of their revisit intention (N. Chen \& Funk, 2010; Hui et al., 2007). The following hypothesis is therefore proposed:

Hypothesis 2d: Satisfaction of tourists with the destination's accommodation services has a direct positive effect on their revisit intention.

The quality of a destination's attractions has also been identified as an important attribute of tourists' satisfaction with a destination. Echtner and Ritchie (1993) observed that tourists consider the quality of attractions as a major criterion for selecting a particular destination. Furthermore, based on observations from Singapore, Hui et al. (2007) empirically demonstrated that tourists from diverse regions considered satisfaction with attractions as an important component of overall satisfaction with a destination:

Hypothesis 2e: Satisfaction of tourists with the destination's tourism attractions has a direct positive effect on their revisit intention.

Tourists have been found to give much importance to the quality of information about a destination which is consequently an important attribute of tourists' 
destination satisfaction. N. Chen and Funk (2010) empirically showed that tourists' devote a lot of importance to the quality of information and support available for a destination. Similarly, J. V. Chen et al. (2017) identified information quality-related attributes such as communication language and usage of telecommunication technologies as relevant predictors of tourists' revisit intention. The latter argued that availability of adequate information through proper communication was linked to the level of perceived risk and, therefore, constitutes an important destination satisfaction component. Accordingly, we propose the following hypothesis:

Hypothesis 2f: Satisfaction of tourists with the destination's information quality has a direct positive effect on their revisit intention.

Political stability and safety has been reported as another important destination attribute for tourists and a determinant of their revisit intention. Mok, Armstrong, and Go (1995) who studied the importance of destination attributes in the context of Hong Kong and Taiwan even found safety to be the most important component. Loi et al. (2017) and Zhang et al. (2017) found that political stability and safety were important antecedents of tourists' revisit intention. J. V. Chen et al. (2017) also found conclusive results with regard to the importance of perceived safety and risks on tourists' revisit intention. The following hypothesis is therefore proposed:

Hypothesis 2g: Satisfaction of tourists with the destination's political stability and safety has a direct positive effect on their revisit intention.

\section{METHOD}

A survey method along with a cross-sectional research design was deemed most appropriate since it allowed to gauge the perceptions of tourists through the collection of primary data from tourists visiting the island of Mauritius. A questionnaire was designed based on the existing literature. Items relating to airport service quality attributes were identified from past literature (e.g., Fodness \& Muray, 2007; Hutchinson et al., 2009) as well as from primary data collection through focus group discussions. As explained hereafter the items were grouped into three components following exploratory factor analysis (EFA), namely, passenger core services, passenger support services, and visitor management services. The scales comprised a total of 13 indicators. A 5-point Likert-type scale was adopted. Satisfaction with other components of the destination added as control variables were also all measured on a 5-point Likert-type scale and were based on Crouch and Richie's (2000) destination experience attributes. Finally, revisit intention was captured through the means of a binary response (yes/no) question.

The questionnaire was administered at the SSR Airport in the waiting lounge. A nonprobability sampling method was preferred to select respondents since the 
questionnaires were only designed for English- and French-speaking tourists. Care was taken to obtain a sample that preserved some important characteristics of the population such as proportion with regard to gender and country of origin. To carry out the survey, a group of research assistants were selected, and they were all fluent in English and French. Based on an appropriate tourist arrival population size, ranging from 850,000 to 975,000 , for the past 5 years prior to the survey, the required sample size that the study should tap so that the model can yield meaningful results was estimated to be 1,721 .

A probit model was used to test for the effects of tourists' satisfaction with airport services and other satisfaction components (cost of living, exchange rate, development level, quality of accommodation, quality of tourism attractions, quality of information, political stability) on their revisit intention, measured on a dichotomous scale.

The empirical model is thus specified as

$$
\mathrm{RT}_{i}=\left(\mathrm{COL}_{i}, \mathrm{ER}_{i}, \mathrm{DEV}_{i}, \mathrm{ACC}_{i}, \mathrm{TA}_{i}, \mathrm{QI}_{i}, \mathrm{PS}, \mathrm{AIR}_{i}, e_{i}\right) .
$$

where, $i$ refers to an individual respondent (i.e., tourists), RT refers to intention to revisit $(1=y e s ; 0=n o)$. The study interestingly also proceeded further by regressing the satisfaction level of disaggregated elements of airport infrastructure, as obtained by the factor analysis performed a priori, for comparative purposes.

\section{RESULTS}

The respondents were evenly distributed with $50.8 \%$ of tourists surveyed being female and male comprising $49.2 \%$. Among the tourists surveyed $42.7 \%$ reported to have previously visited Mauritius. The most popular country of origin was France with $33.4 \%$ of tourists, followed by Great Britain with 20.5\%. Most of the tourists surveyed were in the age group of 19 to 30 years. The majority of tourists surveyed (66.8\%) reported that their length of stay in Mauritius was between 1 and 2 weeks.

Table 1 shows the descriptive statistics with regard to the satisfaction of tourists with airport services attributes measured on a scale of 1 to 5 . As can be observed tourists report a higher than moderate level of satisfaction overall, with mean values above the midpoint value of 3 .

EFA, using varimax rotation, suggested that airport services were composed of three main factors comprising a total of 13 items. The factors/dimensions identified were named as (1) core services, (2) support services, and (3) basic and safety needs services. Observable variables having factor loadings higher than the 0.5 cutoff score as recommended by Hair, Black, Babin, Anderson, and Tatham (2006) were retained, thus, ensuring convergent validity of the measurement scales. The eigenvalues and scree plot demonstrate that the elements are appropriate. The Kaiser-Meyer-Olkin measure of sampling adequacy and the 
Table 1

Descriptive Statistics: Satisfaction With Airport Services

\begin{tabular}{lcccc}
\hline Airport Infrastructure Attribute & $M$ & $S D$ & Skewness & Kurtosis \\
\hline Waiting room at the airport & 3.44 & 1.04 & -.43 & -.17 \\
Baggage claim facilities and delivery & 3.93 & 0.84 & -.65 & .67 \\
Adequacy of baggage trolley & 4.27 & 0.81 & -.92 & .47 \\
Adequacy of check-in facility & 4.09 & 0.90 & -.96 & .98 \\
Customs and immigration & 3.95 & 1.04 & -.95 & .46 \\
Availability of facilities for disabled people & 3.78 & 0.97 & -.47 & -.06 \\
Duty-free shops & 3.51 & 1.04 & -.44 & -.23 \\
Restaurants & 3.24 & 1.07 & -.15 & -.49 \\
Internet/telephone facilities & 3.49 & 1.13 & -.40 & -.45 \\
Rest room/toilet & 3.95 & 0.99 & -.82 & .28 \\
Medical facilities & 3.62 & 0.89 & -.00 & -.15 \\
Airport security & 4.04 & 0.81 & -.54 & .11 \\
Signage/information center & 3.95 & 0.91 & -.72 & .37 \\
Availability of VAT reclaim & 3.65 & 1.01 & -.48 & .07 \\
\hline
\end{tabular}

Note: $M=$ mean; $S D=$ standard deviation; VAT = value-added tax.

Bartlett's test of sphericity both support the solution. The statistical properties are given in Table 2.

While the dimensional structure of airport services was found to be different from that of previous studies such as Bezerra and Gomes (2015), Fodness and Murray (2007) and Lubbe et al. (2011), it still nevertheless contained most of the essential attributes identified in those. Given the new dimensional structure of the airport services satisfaction construct, a modified conceptual model is presented (see Figure 2). The next step was to test for the relationship between the three airport services dimensions and tourists' revisit intention.

The empirical model is thus specified as

$$
\mathrm{RT}_{i}=\left(\mathrm{COL}_{i}, \mathrm{ER}_{i}, \mathrm{DEV}_{i}, \mathrm{ACC}_{i}, \mathrm{TA}_{i}, \mathrm{QI}_{i}, \mathrm{PS}, \mathrm{AIR}_{i}, e_{i}\right)
$$

Table 3 shows the results from the multinomial probit model. The likelihood ratio chi-square of all the models has a probability value of .001, which indicates that, overall, our model is a significant fit.

In line with the extant literature which provides strong support for the link between destination satisfaction and revisit intention (Assaker et al., 2011; Del Bosque \& Martín, 2008; Hutchinson et al., 2009; Petrick et al., 2001; Ranjbarian \& Pool, 2015; Um et al., 2006; Zhang et al., 2017), the overall results show that tourists' satisfaction with the destination has a statistically significant effect on their likelihood to revisit the destination, $p\left(\chi^{2}\right)<.05$. The coefficient of determination $\left(R^{2}\right)$ of $64 \%$, though a "pseudo" one, does provide evidence that the impact of destination satisfaction on tourists' revisit intention is substantial. 
Table 2

Rotated Component Matrix of Respondents' Satisfaction With Airport Infrastructure/Services

\begin{tabular}{lccc}
\hline & \multicolumn{3}{c}{ Component } \\
\cline { 2 - 3 } Infrastructural Elements/Services & 1 & 2 & 3 \\
\hline Waiting room at the airport & .736 & & \\
Baggage claim facilities and delivery & .772 & & \\
Adequacy of baggage trolley & .716 & & \\
Adequacy of check-in facility & .745 & & \\
Customs and immigration facilities & .703 & & \\
Availability of facilities for disabled people & & .671 & .720 \\
Medical facilities & & .615 & .762 \\
Availability of VAT reclaim & & .727 & .726 \\
Duty free shops & & .649 & \\
Internet/telephone facilities & & & 2.343 \\
Rest room/toilet & & & 18.03 \\
Airport security & 3.317 & 2.452 & \\
Signage & 25.51 & 18.86 & .803 \\
Eigenvalue & & .924 & \\
\% of variance explained (62.40\%) & .879 & .842 & \\
KMO & & & \\
Cronbach's $\alpha$ &
\end{tabular}

Note: Component 1 = core services; Component 2 = support services; Component 3 $=$ basic and safety needs servicesKMO $=$ Kaiser-Meyer-Olkin measure; VAT $=$ valueadded tax.

Of primary interest to the present study, the findings further indicate that the satisfaction of tourists with airport services (AIR) significantly increases the probability of tourists revisiting the destination, thus, validating our hypothesis (Hypothesis 1). As mentioned previously, the study probes further by assessing the effects of the three dimensions of airport services on tourists' revisit intention as previously obtained from our EFA, namely, passenger core services (AIR1), passenger support services (AIR2), and basic and safety needs services (AIR3). From Table 3, it can be observed that all the three dimensions are significant predictors of the probability of repeat tourism. Core services is found to be the strongest determinant of revisit intention followed by basic and safety needs services. The results provide evidence for the influence of tourists' satisfaction with the destination's infrastructure, accommodation, attraction, information quality, political stability, and safety on their revisit intention. These findings are in line with the extant literature whereby satisfaction of tourists with those different components were found to predict their intention to return to the destination (J. V. Chen et al., 2017; N. Chen \& Funk, 2010; Hui et al., 2007; Hutchinson et al., 2009; Loi et al., 2017; Ranjbarian \& Pool, 2015; Zhang et al., 
Figure 2

Modified Conceptual Framework

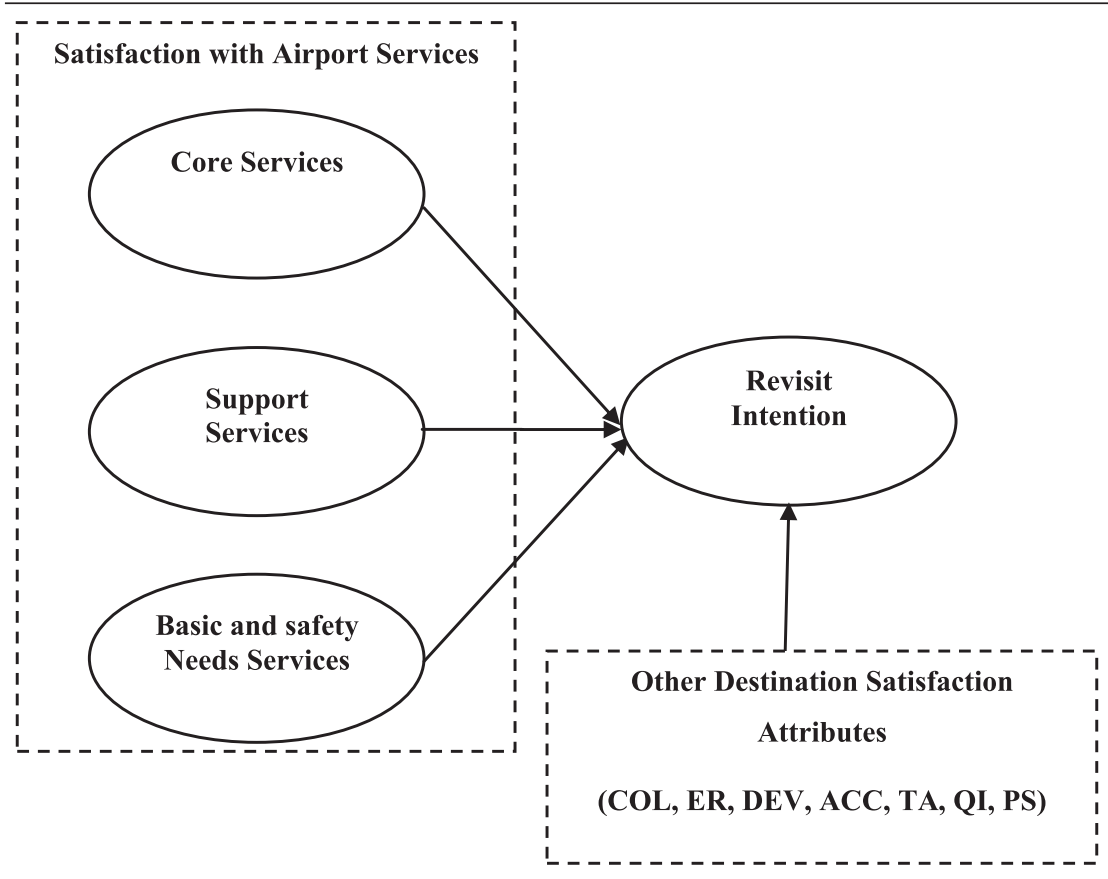

Note: Attributes of cost of living (COL), exchange rate (ER), development level (DEV), quality of accommodation (ACC), quality of tourism attractions (TA), quality of information (QI), political stability (PS) on tourists' revisit intention, measured on a dichotomous scale.

2017). It is noteworthy that among the destination satisfaction dimensions examined, accommodation quality and safety and political stability are found to be the most important predictors of tourists' revisit intention. These were also found to be important determinants of revisit intention by previous studies (e.g., Hui et al., 2007; Mok et al., 1995; Zhang et al., 2017).

It is noteworthy that the cost of living (COL) and exchange rate (ER) were found to be insignificant elements with respect to the probability of revisiting the island. A plausible explanation to the latter would be that the majority of tourists come from developed countries, which have relatively higher cost of living compared with Mauritius. The finding is consistent with Eilat and Einav (2004) who observed that tourists are less sensitive to prices when they travel to less developed countries precisely because of the low existing price level and also that they may choose the destination for value over price. Moreover, the generally depreciating nature of the island's exchange rate vis-a-vis its main tourism originating market, also acting as a cushion any increase in price 
Table 3

Probit Model Estimates

\begin{tabular}{lcccc}
\hline Variable & \multicolumn{2}{c}{ Probit Model Estimates (1) } & \multicolumn{2}{c}{ Probit Model Estimates (2) } \\
\hline Constant & 0.15 & $(4.15)^{\star \star \star}$ & 0.18 & $(3.34)^{\star \star \star}$ \\
COL & -0.011 & -1.02 & -0.03 & -1.05 \\
ER & 0.051 & 0.356 & 0.064 & 0.564 \\
DEV & 0.08 & $(2.87)^{\star \star \star}$ & 0.1 & $(2.67)^{\star \star \star}$ \\
ACC & 0.097 & $(2.35)^{\star \star \star}$ & 0.112 & $(2.31)^{\star \star \star}$ \\
TA & 0.05 & $(2.16)^{\star \star}$ & 0.064 & $(2.33)^{\star \star \star}$ \\
QI & 0.021 & $(2.13)^{\star \star}$ & 0.032 & $(2.10)^{\star \star}$ \\
PS & 0.088 & $(2.77)^{\star \star \star}$ & 0.08 & $(2.44)^{\star \star \star}$ \\
AIR & 0.067 & $(1.97)^{\star \star}$ & & \\
AIR1 & & & 0.095 & $(2.04)^{\star \star}$ \\
AIR2 & & 0.071 & $(1.99)^{\star \star}$ \\
AIR3 & & 0.077 & $(2.34)^{\star \star}$ \\
$R^{2}$ & & & \\
No. of observation & 1,721 & & & \\
Prob chi2 & 0.001 & & & \\
LR chi2(9) & 1364.64 & & \\
\hline
\end{tabular}

Note: $\mathrm{ACC}=$ satisfaction with hotel/accommodation quality; $\mathrm{COL}$ = satisfaction with cost of living; DEV = satisfaction with development level; TA = satisfaction with attractions quality; PS = satisfaction with political stability; QI = satisfaction with quality of information; ER = satisfaction with exchange rate; AIR =satisfaction of tourists with airport services; AIR1 = core services; AIR 2 = support services; AIR3 = basic and safety needs services.

${ }^{*}$ Significance at $10 \% .{ }^{*}$ Significance at $5 \% .{ }^{* \star}$ Significance at $1 \%$.

level of the destination, may provide some element of explanation. Finally, it should also be noted that an overwhelming majority of tourists' booking for the Mauritian destination arise through tour operators (and thus often locked in their local currencies) and also are planned quite in advance, leaving less concern for exchange rate level and fluctuations. Crouch (1995), Dwyer, Forsyth, and Rao, (2002), and Webber (2001) among others, reported the insignificant effect, of exchange rate on tourism, arguing that it was particular to specific country pairs.

\section{CONCLUSIONS}

This study aimed at investigating into the importance of airport services quality in ensuring the satisfaction of tourists with a destination and contributing to their intention to revisit. While the importance of providing satisfactory services to tourists at the airport had been largely discussed in the extant literature, there was a lack of evidence to support such claims and it remained unknown whether the latter would exert an influence on tourists' behavioral intentions. 
The findings provide empirical evidence that the quality of airport services does matter in fostering positive tourists' behaviors, since the more satisfied the latter are with airport services the more likely they are to come back. It is therefore recommended that necessary actions are taken for the maintenance and upgrade of destinations' airport services. In particular, the focus should be on ensuring tourists' satisfaction with airport core services such as the adequacy of waiting rooms, baggage claim facilities, and check-in counters. Major investments for the upgrade of a destination's airport like the one done in Mauritius back in 2013 to the tune of US\$320 million are also likely to be beneficial in the long term given the impact of airport quality on destination satisfaction and loyalty of tourists.

The study is not without limitations, which also provide various avenues for future research. First, this research makes use of a dichotomous scale for measuring tourists' revisit intention. While this was found more convenient for tourists to answer, a multi-item scale using Likert-type scales would provide more precision and allow the use of more sophisticated analysis techniques such as structural equation modelling which also allows for the consideration of measurement errors. Second, data were collected from one specific tourism destination, namely, Mauritius; while Mauritius remains an interesting case given its worldwide reputation for tourism, the results cannot be generalized to other destinations without caution. It is therefore recommended that future studies are carried out in diverse contexts.

\section{REFERENCES}

Assaker, G., Vinzi, V. E., \& O'Connor, P. (2011). Examining the effect of novelty seeking, satisfaction, and destination image on tourists' return pattern: A two factor, nonlinear latent growth model. Tourism Management, 32, 890-901.

Bezerra, G. C. L., \& Gomes, C. F. (2015). The effects of service quality dimensions and passenger characteristics on passengers' overall satisfaction with an airport. Journal of Air Transport Management, 44-45, 77-81.

Brady, M. K., \& Cronin, J. J., Jr. (2001). Some new thoughts on conceptualising perceived service quality: A hierarchical approach. Journal of Marketing, 65, 34-49.

Chao, C. C., Lin, H. C., \& Chen, C. Y. (2013). Enhancing airport service quality: A case study of Kaohsiung international airport. Journal of the Eastern Asia Society for Transportation Studies, 10, 2235-2254.

Chen, C.-F., \& Tsai, D. C. (2007). How destination image and evaluative factors affect behavioral intentions? Tourism Management, 28, 1115-1122.

Chen, C.-F., \& Chen, F.-S. (2010). Experience quality, perceived value, satisfaction and behavioral intentions for heritage tourists. Tourism Management, 31, 29-35.

Chen, J. S., \& Gursoy, D. (2001). An investigation of tourists' destination loyalty and preferences. International Journal of Contemporary Hospitality Management, 13, 79-85.

Chen, J. V., Htaik, S., Hiele, T. M. B., \& Chen, C. (2017). Investigating international tourists' intention to revisit Myanmar based on need gratification, flow experience and perceived risk. Journal of Quality Assurance in Hospitality and Tourism, 18, $25-44$. 
Chen, N., \& Funk, D. C. (2010). Exploring destination image, experience and revisit intention: A comparison of sport and non-sport tourist perceptions. Journal of Sport \& Tourism, 15, 239-259.

Chi, C., \& Qu, H. (2008). Examining the structural relationships of destination image, tourist satisfaction and destination loyalty: An integrated approach. Tourism Management, 29, 624-636.

Choo, H., \& Petrick, J. F. (2014). Social interactions and intentions to revisit for agritourism service encounters. Tourism Management, 40, 372-381.

Cole, S. T., \& Scott, D. (2004). Examining the mediating role of experience quality in a model of tourist experiences. Journal of Travel \& Tourism Marketing, 16, 79-90.

Crompton, J. (1992). Structure of vacation destination choice sets. Annals of Tourism Research, 19, 420-434.

Cronin, J. J., Jr., Brady, M. K., \& Hult, G. T. M. (2000). Assessing the effects of quality, value and customer satisfaction on consumer behavioral intentions in service environments. Journal of Retailing, 76, 193-218.

Crouch, G. I. (1995). A meta-analysis of tourism demand. Annals of Tourism Research, 22, 103-118.

Crouch, G. I., \& Ritchie, J. R. B. (2000). The competitive destination: A sustainability perspective. Tourism Management, 21(2), 1-7.

Danaher, P. J., \& Arweiler, N. (1996). Customer satisfaction in the tourist industry: A case study of visitors to New Zealand. Journal of Travel Research, 35, 89-93.

Del Bosque, I. R., \& Martín, H. S. (2008). Tourist satisfaction: A cognitive-affective model. Annals of Tourism Research, 35, 551-573.

Dwyer, L., Forsyth, P., \& Rao, P. (2002). Destination price competitiveness: Exchange rate changes versus domestic inflation. Journal of Travel Research, 40, 328-336.

Echtner, C. M., \& Ritchie, J. R. B. (1993). The measurement of destination image: An empirical assessment. Journal of Travel Research, 31(4), 3-13.

Eilat, Y., \& Einav, L. (2004). Determinants of international tourism: A three-dimensional panel data analysis. Applied Economics, 36, 1315-1327.

Fodness, D., \& Murray, B. (2007). Passengers' expectations of airport service quality. Journal of Services Marketing, 21, 492-506.

Fornell, C. (1992). A national customer satisfaction barometer: The Swedish Experience, Journal of Marketing, 56, 6-21.

Hair, J., Black, W. C., Babin, B. J., Anderson, R. E., \& Tatham, R. (2006). Multivariate data analysis. New York, NY: Pearson Education.

Hui, K. T., Wan, D., \& Ho, A. (2007). Tourists' satisfaction, recommendation revisiting Singapore. Tourism Management, 28, 965-975.

Hung, W.-L., Lee, Y.-J., \& Huang, P. H. (2016). Creative experiences, memorability and revisit intention in creative tourism. Current Issues in Tourism, 19, 763-770.

Hutchinson, J., Lai, F., \& Wang, Y. (2009). Understanding the relationships of quality, value, equity, satisfaction, and behavioral intentions among golf travelers. Tourism Management, 30, 298-308.

Khadaroo, J., \& Seetanah, B. (2007). Transport infrastructure and tourism development. Annals of Tourism Research, 34, 1021-1032.

Kim, S., Park, J. H., Lee, D. K., Son, Y. H., Yoon, H., Kim, S., \& Yun, H. J. (2017). The impacts of weather on tourist satisfaction and revisit intention: A study of South Korean domestic tourism. Asia Pacific Journal of Tourism Research, 22, 895-908. 
Kozak, M., (2001). Repeaters' behavior at two distinct destinations. Annals of Tourism Research, 28, 784-807.

Ladhari, R. (2009). A review of twenty years of SERVQUAL research. International Journal of Quality and Service Sciences, 1, 172-198.

Lee, C. K., Lee, Y. K., \& Lee, B. (2005). Korea's destination image formed by the 2002 World Cup. Annals of Tourism Research, 32, 839-858.

Loi, L. T. I., So, A. S. I., Lo, I. S., \& Fong, L. H. N. (2017). Does the quality of tourist shuttles influence revisit intention through destination image and satisfaction? The case of Macao. Journal of Hospitality \& Tourism Management, 32, 115-123.

Lubbe, B., Douglas, A., \& Zambellis, J. (2011). An application of the airport service quality model in South Africa. Journal of Air Transport Management, 17, 224-227.

Martín-Cejas, R. (2006). Tourism service quality begins at the airport. Tourism Management, 27, 874-877.

Mok, C., Armstrong, R. W., \& Go, F. M. (1995). Taiwanese travellers' perception of leisure destination attributes. Australian Journal of Hospitality Management, 2, 17-22.

Petrick, J. F., Morais, D. B., \& Norman, W. (2001). An examination of the determinants of entertainment vacationers' intentions to visit. Journal of Travel Research, 40, 41-48.

Pizam, A., \& Milman, A. (1993). Predicting satisfaction among first time visitors to a destination by using the expectancy disconfirmation theory. International Journal of Hospitality Management, 12, 197-209.

Quintal, V. A., \& Polczynski, A. (2010). Factors influencing tourists' revisit intentions. Asia Pacific Journal of Marketing and Logistics, 22, 554-578.

Ranjbarian, B., \& Pool, J. K. (2015). The impact of perceived quality and value on tourists' satisfaction and intention to revisit Nowshahr city of Iran. Journal of Quality Assurance in Hospitality \& Tourism, 16, 103-117.

Seyanont, A. (2011). Passengers' perspective toward airport service quality at Suvarnabhumi International Airport (Unpublished doctoral dissertation). University of the Thai Chamber of Commerce, Krung Thep Maha Nakhon, Thailand.

Stylos, N., Bellou, V., Andronikidis, A., \& Vassiliadis, C. A. (2017). Linking the dots among destination images, place attachment, and revisit intentions: A study among British and Russian tourists. Tourism Management, 60, 15-29.

Sureshchandar, G. S., Rajendran, C., \& Anantharaman, R. N. (2002). The relationship between service quality and customer satisfaction-A factor specific approach. Journal of Services Marketing, 16, 363-379.

Thompson, K., \& Schofield, P. (2007). An investigation of the relationship between public transport performance and destination satisfaction. Journal of Transport Geography, 15, 136-144.

Tsai, W.-H., Hsu, W., \& Chou, W.-C. (2011). A gap analysis model for improving airport service quality. Total Quality Management \& Business Excellence, 22, 1025-1040.

Um, S., Chon, K., \& Ro, Y. H. (2006). Antecedents of revisit intention. Annals of Tourism Research, 33, 1141-1158.

Webber, A. G. (2001). Exchange rate volatility and cointegration in tourism demand. Journal of Travel Research, 39, 398.

Yeh, C. H., \& Kuo, Y. L. (2003). Evaluating passenger services of Asia-Pacific international airports. Transportation Research Part E: Logistics and Transportation Review, 39, 35-48. 
Zeithaml, V. A., Berry, L. L., \& Parasuraman, A. (1996). The behavioural consequences of service quality. Journal of Marketing Management, 60(4), 31-46.

Zhang, H., Wu, Y., \& Buhalis, D. (2017). A model of perceived image, memorable tourism experiences and revisit intention. Journal of Destination Marketing and Management, June, 1-11.

\section{Submitted May 10, 2017}

Accepted July 17, 2018

Refereed Anonymously

Boopen Seetanah, PhD (b.seetanah@uom.ac.mu), is an Associate Professor at the Faculty of Law and Management, University of Mauritius, Reduit, Mauritius. Viraiyen Teeroovengadum, PhD (v.teeroovengadum@uom.ac.mu), is a Senior Lecturer at the Faculty of Law and Management, University of Mauritius, Reduit, Mauritius. Robin S Nunkoo, PhD (r.nunkoo@uom.ac.mu), is an Associate Professor at the Faculty of Law and Management, University of Mauritius, Reduit, Mauritius 